\title{
Intensive Economic Growth in Jordan during 1978-2010
}

\author{
Shatha Abdul-Khaliq ${ }^{1}$, Thikraiat Soufan $^{1} \&$ Ruba Abu Shihab ${ }^{2}$ \\ ${ }^{1}$ Al Zaytoonah Private University of Jordan, Jordan \\ ${ }^{2}$ AlBlqa Applied University, Jordan \\ Correspondence: Shatha Abdul-Khaliq, Al Zaytoonah Private University of Jordan, Jordan. E-mail: \\ yshatha@gmail.com
}

Received: March 12, 2013 Accepted: May 2, 2013 Online Published: May 24, 2013

doi:10.5539/ijbm.v8n12p143 URL: http://dx.doi.org/10.5539/ijbm.v8n12p143

\begin{abstract}
The research aims to study the economic growth in Jordan using the Solow model during the period 1978-2010, it was found that the rate of economic growth depends on the intensive growth which reflects on intangible aspects that does not reflect changes visible in the accumulation of factors of production rather than the expanded growth through increasing the capital and labor.
\end{abstract}

Keywords: economic growth, human capital, GDP, Solow mode, intensive growth, expanded growth

\section{Introduction}

\subsection{Explore the Importance}

The economist Alfred Marshall confirmed that the importance of investing is in human capital as a national investment, noting that the best types of capital value is capital that invests in the human, as the key to the progress of nations and people, it is through the development of human resources, which shift wealth from just amounts to quality and creative energies and technology with a variety of contributions effective in achieving the desired progress. Examples of the impact of investment in human capital in the progress and economic and social growth is multiple, and Human capital is the element that gives people the ability to achieve their incomes which can be increased through education and training, health care and economists see that the accumulation of human capital and physical is important in condition for economic growth.

Economic growth depends on a range of variables, and most important is capital increase through investment and capital accumulation, and the increase in workforce that affect the economic growth through the quality of work and productivity and spending on improving and developing the quality of work including the investment in human, where it is investing in manpower and capital in parallel, the accumulation of human capital affect the production process, and extends to improving the quality of production, in addition to reducing the cost of its ability to use modern technological methods and ability to innovation and creativity.

The experiences of the availability of skilled labor have showed a minimum of education, consistent with rapid technological changes, achieve economic growth rates in the long term, and focused recent studies on a relationship and link between economic growth and human capital accumulation, and investment which have a positive impact on economic growth and this study comes to the source of economic growth in Jordan, which depends on the investments and the labor force on the one hand and improve the overall productivity of the factors of production that are not reflected in the visual changes in the accumulation of factors of production such as improving the technology used and the level of education and training for individuals.

Also there are many other factors like monetary policy, the size of government expenditures, foreign trade, and inflation are considered as a factors affecting economic growth.

\subsection{Hypothesis}

The first hypothesis:

Assume that production depends on the expanded growth through increasing the capital and labor is positive.

The second hypothesis:

Assume that production depends on the intensive growth which reflects on intangible aspects that does not reflect changes visible in the accumulation of factors of production through monetary policy, the size of 
government expenditures, foreign trade, teaching and inflation is positive.

\section{Previous Studies}

We summarize some studies that addressed the issue of human capital and economic growth as follows:

The (Shaw, 1973) a study of financial development in economic growth find out that increasing interest rate will increase the saving then investment.

The (Creane, Goyal, Mobarak \& Sab, 2003) a study on financial development and economic growth in the Middle East and North Africafor using twenty countries, including Jordan, to confirm the comprehensive financial development of monetary policy, financial openness, institutional capacity and regulation.

The (Barro, 1991), a study on the determinants of growth in many economies for about one hundred countries, pointing out that there are many variables that influence on the rate of growth in the long term as the education level and the ratio of investment and political stability.

Also the study of (Narayan and Smyth 2004) aimed to identify a causal relationship between human capital and real income in China during the period 1999 to 1960by using the cointegration tests and the Granger. The results of this study in the long term is a one-way causal relationship going from human capital to real income either in the short term there is a one-way causal relationship going from real income to human capital.

The study of (De Meulemeester and Rochat, 1995) tested the relationship between the percentage of students enrolled in higher education and economic growth in 6 countries: Sweden, (1975 - 1885) Japan, (1987 - 1919) United Kingdom, (1986 - 1910). (1986 - 1906) Australia, (1986 - 1885), Italy (1986 - 1899) France. The results of this study through the relationship by one-way going through proportion of students enrolled in higher education to economic growth in the short term in all of Sweden, Japan, and France. The results of the study to a neutral relationship between the proportion of students enrolled in higher economic growth in both Australia and Italy.

The study of (Zu'bi \& et. al, 2004) showed the impact of human capital and exports on economic growth in Jordan - A Case Study of the governorate of Irbid during the period (1979-2000) showed the relationship between the accumulation of human capital relative to total employment and GDP growth. The results showed a positive relationship between economic growth and the demand for qualified labor came standard model results are consistent with the hypotheses of the form in the industrial export sector positively influenced by the accumulation of human capital.

The study of (Virmani, 2012 showed lessons from the experience of fast growing economies including a sub-set of these termed High Growth Economies (HGEs) with a decadal rate of over 7 per cent. It then reviewed the history of the Indian growth acceleration following the reforms of the 1990s and its future prospects given the recent slowdown. It analyzed the potential dangers and reasons for India's growth slowdown and proposes policy reforms for sustaining fast growth.

\section{Method}

The descriptive statistical methods were followed through standard methods for the interpretation of some relationships, in order to achieve the objectives of this study to find out the source of Jordan's economic growth using annual data for Jordan during the period of $1978-2010$.

\section{Economic Growth Theories}

Economic Growth Theories reflect on the continuous increase in the gross national product, because of the interaction that occurs in a given environment in a certain time period, including various changes in the presentation of productive factors in society labor, capital and natural resources, to lead these radical changes to increase successive demand on commodities, and hence an increase in national income (Namik, 1965).

Adam Smith principle of specialization and division of labor called to raise productivity and production, which are both of impact in increasing the skill of workers, and the economic time to do the work, and then will turn to a larger amount of capital due to the discovery of art new production, thereby increasing income and savings,

On the other hand, the Malts theory of economic growth considered an echo of his theory in the population, which is based on the population to grow by nearly geometric progression, and this leads to an increase in effective demand, which will affect the economic growth. Also Malts idea of economic growth linked to increase profits in the hands of producers, leading to increased production, which includes economic growth, as confirmed by the importance of saving and investment as workers in economic growth, also saving leads to a reduction of effective demand will lead to lower economic growth (Kuznets, 1966). 
The Solow model is cornerstone of economic growth in the neoclassical theory, which is based on the primary source of long-term growth in technological progress as one of the elements of production factors and which is exogenous variable.

The components of the production process is based on three elements, labor, capital and technology knowledge, and these elements are essential inputs for output of goods and services, and the capital inputs in kind and concrete machinery and land, while the labor force in the community contribute to the production process, which depends on the degree of skill workers.

Improving worker productivity achieved in investing in human capital through attention to educational level and health of workers is to increase their skills, as technology in the knowledge used for adaptation and development of capital and labor to get the output (Romar, 1996).

In the view of neoclassical theory in the economy can not achieve the growth rates in the long term by increasing the rate of investment in capital only, because the rate of increase in growth will decrease even fading by law of diminishing returns, but that the main source of long-term growth is technological development as a component of the overall.

While the growth theory of modern growth see the procedure that there are several sources of growth focuses on the technological development which is determined within the model and not from outside as in the neoclassical theory (Endogenous Growth), and they are similar to the neoclassical theory by the ability of labor to increase productivity achieved through investment in human capital to raise the educational level of workers, the skills and experience. it beats the law of diminishing returns by investing in labor and capital in parallel with what is known in human capital, and the production function is homogenous and the capital ratio to production automatically change with change ratio of capital to labor, and the balance in the long term happens when real production of capital equal to the change in the ratio of capital to labor, and affect change in the rate of growth of the labor in the change of the rate of growth in the long term (Romar 1996).

\section{The Sources of Economic Growth}

Sources of economic growth from the supply side based on the growth of production inputs, which include capital and labor mainly in the growth of productivity and efficiency of the use of these inputs, where it is known intensive economic growth if the growth is based on improved overall productivity of factors of production, while known the extensive in economic growth if the growth is based on increasing capital and labor.

\subsection{Investment}

Investment is defined as abandoned funds owned individual at a given moment and linked the origin of assets held for that period of time, in order to obtain financial flows future compensated for the present value of money abandoned or decreasing in the purchasing power of those funds by inflation, (Ramadan, 1997).

The key to the economic growth process is the formation of capital by increasing the size of the domestic savings and increasing the investment, which provides by financial sector by mobilizing savings, and the size of the investment is affected by the size in the real source of savings to finance investment projects in the productive sectors.

\subsection{Employment and Population Growth}

Employment affects on economic growth through the quality of work, productivity and spending to improve and develop the quality of work including the spending on human investment by investing in labor and capital in parallel.

Accumulation of human capital affects the production process, to double the production because of the skill possessed by neither worker nor limited impact on increasing productivity, but extends to improving the quality of production, in addition to reducing the cost of its ability to use modern technological methods and ability to innovation and creativity.

Skilled labor for workers move from sector to another without cost to the sector in order to train and qualify to cope with the conditions of production, which leads to competitive sectors to attract these experiences to draw, and the availability of qualified labor is a reason to attract foreign investment, at a time the countries seek to provide investment environment through laws and regulations that only provide qualified labor able to deal with modern technology.

Some economists see that the reason for maintaining the economic growth long-term is due to the growth in human capital accumulation, cause of direct contribution to improving the quality and efficiency of the workforce, as well as improving the quality of physical capital, which leads to increased productivity of factors 
of production, also increasing revenues.

According to models internal growth provided by (Romer 1990), creating new ideas is a function proportional in human capital ,sense that human capital takes the form of scientific knowledge that leads to the creation of new ideas, therefore investment in human capital will cause an increase in capital.

\subsection{Technology}

The importance of technology and technical progress as a factor in economic growth, operate new methods to increase production and improve the quality that require more investment, due to lower costs and increase revenue, working to increase sufficiently marginal efficiency of capital through increased investment to inventions.

The theory of Harry Jonson explains the expansion of the range of technological and its impact on economic growth as one of the theories of international trade, by increasing industrial products of intensive technology which known as commodities of product cycle, that undergoes by research and development of the product also by phase stability of technical methods that develop for production, to be able to produce new goods in monopoly market, and finally the production stage that produce typical goods through the transmission technology methods to be competitive (Jones, 1978).

\subsection{Monetary Policy}

The Target of monetary policy influences monetary variables by central bank such as money supply and credit volume and interest rate and exchange rate.

monetary policy is considered one of the factors affecting investment and economic growth indirectly by influencing the interest rate and impact on the size of the investment then aggregate demand and economic growth,(Shkoukani, 2005).

\subsection{Government Spending}

The size of government expenditures linked by development of the country, so when the country grows government increases spending and its impact on GDP and therefore the rate of economic growth.

\subsection{Foreign Trade}

Foreign trade sector contributes to meet the needs of consumer goods, capital and raw materials. Openness Economic and expansion of foreign trade leads to good directing the resources of countries in addition maintain the level of imports not to increased and compete the domestic goods, which affect increase negatively on the size of savings and therefore lower investment.

The theory of absolute advantage by Adam Smith that foreign trade are beneficial to all parties and also take a part in the optimal allocation of factors of production and increase capital accumulation and raise the productive capacity and increase economic growth.

\subsection{Inflation}

Inflation is the continuing rise in the general price level for a long time, represented a decrease of purchasing power through a negative impact on the level of national income, and lower the standard of living then decrease saving, due to increased consumption, then decrease investment and economic growth rate.

\section{Economic Growth in Jordan}

Jordan in the recent years offset the lack in natural resources through the outstanding level in human resources, and by leading a policy of openness to the global markets. Jordan succeeded in economic policies by achieving fiscal and monetary stability and by creating a legislative investment environment, having been conducting many of privatization and structural reforms that contributed to accommodation for the private sector of the economy through supplement investments which contributed to raising the efficiency of the Jordanian economy and putting it in the path of growth and progress.

The stages of economic growth in Jordan as follows:

1-The stage of the economic boom period (1978-1982)

This stage is Characterized by the average growth rate of GDP in the amount of $14.2 \%$ and the average size of the investment reach a rate of $37.5 \%$ as a percentage of gross domestic product for the period, also investment focus on the private sector building and construction which generates the income and employment, also adopted the economic growth for this period on external funding, and was financing the construction of the private sector through workers' remittances, while the infrastructure and key projects set up by the state have been funded 
through the aid received by the government of oil-producing countries, which amounted of GDP average $15.2 \%$ for the period 1978-1982.

2-The stage of the economic slowdown for the period (1983-1987)

This period saw a decline in oil prices, which led to a decline in workers' remittances of Jordanians and Arab aids, which led to a deficit in the current account of $5.2 \%$ of GDP, and this in turn led to a decline in the average size of investment to a rate of $25.3 \%$ of GDP for this stage, but in contrast the average fiscal deficit to $3.9 \%$ as a percentage of GDP for this period to be the result of a decline in the average rate of GDP growth would amount to $1.4 \%$ for the period $1983-1987$.

3-The stage of the economic crisis for the period (1988-1991)

This stage came a result of the economic crisis that occurred on the impact of the collapse of the dinar exchange rate in 1988 and the Gulf War in 1990, which led to the decline in the rate of GDP growth to negative growth rate of $2 \%$ for the period 1988-1991, and due to the increasing fiscal deficit and increasing debt service ratio to $45.4 \%$ of exports in 1989 , which led to government borrowing to meet this deficit, also led to the high rate of inflation to a rate of $13.5 \%$ in 1988 , and the decline in investment to $22.7 \%$ as a percentage of GDP for the same year, and ultimately fell in GDP that increased by $21 \%$ as a result of the recession period in the Jordanian economy in 1989.

The result of the economic crisis in 1988 was the adoption of a comprehensive program of economic reform and structural cooperation with the International Monetary Fund and the World Bank to promote economic growth were to start applying the first program in 1989 to cover the period 1989-1993, by using a concretionary monetary policy to reduce the inflation effects in the program of debugging Economy as well as promote the development of foreign reserves as a tool to maintain the stability of the dinar exchange rate and peg to the dollar and reduce the margin between the official exchange rate and the free exchange rate to cover all economic transactions visible and invisible since February 1990, in addition to promoting national exports to cancel the requirement to provide bank guarantee for Exports of goods Jordanian origin, as the central bank cut its minimum ratio of cash margins charged by banks on the import of raw materials used in the domestic industry.

4-The stage of economic recovery for the period (1992-1995)

Jordanian economy continued on the road to real economic growth despite the crisis the Arabian Gulf that have hindered the continuous application program debugging economy ,because of carrying the Jordanian economy additional burdens and losses as a result the economic blockade and international sanctions imposed on Iraq that stopped the aid and workers' remittances of Jordanians in the Gulf, so that characterized this period increase the average size of investments to $34 \%$ for the period 1992-1995, resulting in a higher average economic growth rate to $7.5 \%$ for the same period, due to the return of 300 thousand Jordanian workers from the Gulf after the Gulf War with the savings to Jordan, along with results of the application of another program to correct covering the period 1992-1998, which represented an increase of average economic growth rate to 5.5\% for the period 1992 1998 which is higher than the growth rate of the goal of the program to achieve 4.3\% for the period 1992-1998.

5-The stage of the economic slowdown for the period 1996-1999

economic reform policies Succeeded for the period 1992-1998 in achieving its short-term goals and of achieving financial and monetary stability with the end of 1998 , to control inflation to a rate of $4.4 \%$ annually in 1998 , in addition to controlling the budget deficit within the limits of 5\% in1997 and 8.5\% in 1998, also a decline in the expenses growth to become positive as a result to debt rearrangement during 2002-2003.

In 1998 Jordan was affected in declining the global oil prices which has led to the interruption of financial assistance to Jordan, by contrast, that has been the development of local revenue by issuing a new law of Customs which was to unite all fees and taxes collected on goods imported and re-exported. On the other hand reflection negatively on the size of Jordan trade with Arab countries exporting oil, also weak competitiveness of the industry of Jordan and its dependence on the domestic market and the high cost because of the small size of the production so that decreased total commodity exports and services, including 4.5 percent for 1998 when compared with 1997, thus the above factors may have influenced negatively on the level of economic activity to achieve average annual growth rate of $2.9 \%$ of GDP for the period 1996-1999, which called for the adoption of the correct program for the period 1999-2001.

6-The stage of moderate growth for the period (2000-2007)

The moderate growth rate reached $4.4 \%$ for the period 2000-2002 cause of the impact of using expansionary monetary policy and was adapted to local and international economic conditions by achieving reform program 
for 1999-2001 improvement in the performance of trade of exports and services to an average of $42.5 \%$ for the period 1999-2001, and decreased the deficit in the including trade balance by $5.7 \%$ compared with the previous stage to reach an average of $27.7 \%$ as a percentage of GDP for the period 1999-2001.

Also been reached in the month of July 2002 an agreement with the IMF on a a new program of economic reform begins in 2002 and extends until 2004, and includes fiscal policy aims to provide the conditions for economic growth and contribute to the positive impact on people's living standards and maintain exchange rate stability and an appropriate level of foreign exchange reserves, in addition to continuing to work to reduce the public debt as a percentage of GDP.

Jordan had positive results at the end of this program and reached an average growth rate of real GDP of $8.3 \%$ for the period of application of the program, continued Jordan in growth rate of GDP stood at $8.2 \%$ in 2007, and through the implementation of investment quality and quantity in the areas of local development, and the development of programs aims to empower citizens and provide appropriate opportunities, especially youth and women, as well as encouraging and promoting private investment.

7-The stage of the global financial crisis (2008-2010)

Signs of the global financial crisis were to emerge in September 2008 in the United States and moved quickly to the most advanced economies and then spread globally, and implications of the crisis came on countries varying in intensity and speed of impact, according to the degree of openness of their economies in general on the global economy with its components that were different, and exposure economy ,for Jordanian global financial crisis and consequent recession in the economies of most developed and developing countries over the past 2008, 2009 and 2010, where had begun a growth rate of Jordan GDP reached to $7.2 \%$ and $5.5 \%$ and $2.3 \%$ for the years 2008 , 2009 and 2010 respectively .

\section{Sources of Economic Growth in Jordan for the Period 1978-2010}

\subsection{Statistical and Econometrics Analysis}

Modern economic theories showed that the volume of production is based on an increase of capital through investment and capital accumulation, and increase the labor and improve the overall factors of production, and will identify indicators of economic growth through model (Solow), as follows:

$$
y=k^{b} x
$$

$\mathrm{k}$ : the proportion of capital per worker.

$\mathrm{y}$ : proportion of gross domestic product (GDP) per worker.

$\mathrm{x}$ : other factors that affect growth and known as Solow residual, and include: human capital by taking the logarithm of the equation becomes as follows:

$$
G D P=b G K+E F F
$$

The previous equation represents the factors affecting on economic growth, considering that employment will represent the number of population is as follows:

GDP: growth rate of per capita GDP.

GK: growth rate of per capita of total capital.

EEF: Growth rate of everything else.

In this context will use the following calculation methods to calculate the sources of economic growth:

Per capita GDP $=$ GDP $/$ population .

Per capita total capital $=$ total capital $/$ population .

And using the following equation:

$$
E F F=G D P-b G K
$$

Using statistical data that were obtained for the period 1978-2010 and the application of Equation 3, we get the growth rate for the overall productivity of factors of production in Jordan which is shown in Table (3)

Rate of change were calculated in the rate of growth of productivity of factors of production based on the results in Table (4).

Analysis of the previous tables include: 
1) The average annual growth rate of per capita of the total capital is $5.9 \%$ for the period $1978-2010$, while the average annual growth rate of total factor productivity is $6.1 \%$ for the period $1978-2010$, and the average annual growth of per capita GDP is $7.2 \%$.

2) The average annual gross capital formation to GDP accounted for $28.2 \%$ for the period $1978-2010$.

3) The average contribution rate of growth of total factor productivity accounted for $37.8 \%$ in the average rate of GDP growth for the period 1978-2010, where we note that there is a significant change in the proportion of the contribution to the growth rate of total factor productivity in the average rate of GDP growth for the period 1978-2010, which indicates that the growth rate of total factors productivity is linked to the economic situation and the political events surrounding the area, and the quality of the investment climate.

The percentage of the economic boom of the average change rate of growth of total factor productivity was $1.23 \%$ for the period 1978-1982, and then fell in the period of economic slowdown which covers the period $1983-1987$ to an average of $0.05 \%$, bringing the decline to a rate of $1.18 \%$ in the period of economic crisis, covering the period 1988-1991 and resulting from the collapse of the exchange rate of the Jordanian dinar in 1988 and the Gulf War in 1990.

We also note high percentage change in the average change rate of growth of total factor productivity in the period of economic recovery for the period $1992-1995$ is $0.26 \%$ for up to a rate of $0.39 \%$ for the period 1996 1999 , and that resulted the impact of the adoption of a comprehensive program of economic reform and structure to reach a rate of $0.8 \%$ in a period of moderate growth for the period $2000-2007$, then to $0.6 \%$ due to the global financial crisis that affected Jordan .

The percentage of contribution to the growth rate of total factors productivity accounted for $37.8 \%$ in the average rate of GDP growth for the period 1978-2010 in Jordan while the study found (Arab Monetary Fund, 2002) that the percentage contribution of total factor productivity in economic growth is not more than $30 \%$ in Arab countries, which means that Jordan started depending on intensive growth which reflects the intangible aspects that are not reflected in the visual changes in the accumulation of factors of production, rather than expanded growth of increasing the amount of production by increasing capital and labor.

Table 1. Average growth per capita GDP in Jordan (1978-2010)

\begin{tabular}{ccc}
\hline $\log ($ GDP /Number of population)*** & Per capita GDP & Year \\
\hline 6.9 & 1032.0 & 1978 \\
7.1 & 1188.3 & 1979 \\
7.1 & 1262.0 & 1980 \\
7.3 & 14234.0 & 1981 \\
7.3 & 1468.1 & 1982 \\
7.2 & 1381.2 & 1983 \\
7.2 & 1386.7 & 1984 \\
7.2 & 1298.7 & 1985 \\
7.2 & 1318.9 & 1986 \\
7.2 & 1299.1 & 1987 \\
7.2 & 1268.8 & 1988 \\
7.0 & 1090.6 & 1989 \\
6.9 & 986.0 & 1990 \\
6.8 & 938.7 & 1991 \\
6.9 & 1033.5 & 1992 \\
6.9 & 1039.6 & 1993 \\
7.0 & 1052.8 & 1994 \\
7.0 & 1085.3 & 1995 \\
7.0 & 1077.7 & 1996 \\
7.0 & 1083.1 & 1997 \\
7.0 & 1087.5 & 1998 \\
7.0 & 1093.6 & 1999 \\
7.0 & 1110.5 & 2000 \\
7.0 & 1136.6 & 2001 \\
7.1 & 1163.3 & 2002 \\
\hline
\end{tabular}




\begin{tabular}{lll}
\hline 7.1 & 1180.5 & 2003 \\
7.1 & 1242.8 & 2004 \\
8.3 & 4055,8 & 2005 \\
7.3 & 1424,4 & 2006 \\
7.3 & 1507,8 & 2007 \\
7.4 & 1581,8 & 2008 \\
7.4 & 1632,1 & 2009 \\
7.4 & 1633,5 & 2010 \\
\hline
\end{tabular}

*the value is million Jordanian dinar refer to the base year 1994.

**million.

***nearly to the first digit.

Sources: 1977-2002 years (central bank 2004); 2003-2010 years (central bank statistical report, Vol. 41, Num. 12, 2005)

Table 2. Per capita of the total capital in Jordan (1978-2010)

\begin{tabular}{|c|c|c|}
\hline $\log$ (Gross capital accumulation /Number of population & Per capita of the total capital & Year \\
\hline 5.8 & 341.4 & 1978 \\
\hline 5.9 & 374.8 & 1979 \\
\hline 6.2 & 469.1 & 1980 \\
\hline 6.5 & 655.4 & 1981 \\
\hline 6.4 & 578.7 & 1982 \\
\hline 6.1 & 456.0 & 1983 \\
\hline 6.0 & 414.8 & 1984 \\
\hline 5.6 & 273.4 & 1985 \\
\hline 5.6 & 261.6 & 1986 \\
\hline 5.7 & 293.0 & 1987 \\
\hline 5.7 & 287.6 & 1988 \\
\hline 5.5 & 253.4 & 1989 \\
\hline 5.7 & 303.7 & 1990 \\
\hline 5.5 & 234.4 & 1991 \\
\hline 5.8 & 346.0 & 1992 \\
\hline 5.9 & 380.8 & 1993 \\
\hline 5.9 & 350.6 & 1994 \\
\hline 5.9 & 357.7 & 1995 \\
\hline 5.8 & 328.9 & 1996 \\
\hline 5.6 & 278.7 & 1997 \\
\hline 5.5 & 237.3 & 1998 \\
\hline 5.5 & 236.1 & 1999 \\
\hline 5.5 & 246.1 & 2000 \\
\hline 5.5 & 236.3 & 2001 \\
\hline 5.5 & 233.9 & 2002 \\
\hline 5.5 & 245.4 & 2003 \\
\hline 5.8 & 337.2 & 2004 \\
\hline 7.2 & 1385,0 & 2005 \\
\hline 6 & 403,7 & 2006 \\
\hline 6.2 & 456,4 & 2007 \\
\hline 6.1 & 472,9 & 2008 \\
\hline 6.2 & 429,2 & 2009 \\
\hline 6 & 405,9 & $2010 *$ \\
\hline
\end{tabular}

Sources: 1977-2002 years (central bank 2004); 2003-2010 years (central bank statistical report, Vol. 41, Num. 12, 2005) 
Table 3. Growth in the total factors productivity in Jordan (1978-2010)*

\begin{tabular}{|c|c|c|c|}
\hline $\begin{array}{c}\text { Total factors productivity growth rate } \% \\
\text { EEF }=\text { GDP- } b * G K\end{array}$ & $\begin{array}{l}\text { Per capita of the total } \\
\text { capital growth rate*\% }\end{array}$ & $\begin{array}{l}\text { Per capita GDP } \\
\text { growth rate } \%\end{array}$ & Year \\
\hline 5.8 & 5.8 & 6.9 & 1978 \\
\hline 5.9 & 5.9 & 7.1 & 1979 \\
\hline 5.9 & 6.2 & 7.1 & 1980 \\
\hline 6.0 & 6.5 & 7.3 & 1981 \\
\hline 6.0 & 6.4 & 7.3 & 1982 \\
\hline 6.0 & 6.1 & 7.2 & 1983 \\
\hline 6.0 & 6.0 & 7.2 & 1984 \\
\hline 6.0 & 5.6 & 7.2 & 1985 \\
\hline 6.1 & 5.6 & 7.2 & 1986 \\
\hline 6.0 & 5.7 & 7.2 & 1987 \\
\hline 6.0 & 5.7 & 7.2 & 1988 \\
\hline 5.9 & 5.5 & 7.0 & 1989 \\
\hline 5.8 & 5.7 & 6.9 & 1990 \\
\hline 5.8 & 5.5 & 6.8 & 1991 \\
\hline 5.8 & 5.8 & 6.9 & 1992 \\
\hline 5.8 & 5.9 & 6.9 & 1993 \\
\hline 5.8 & 5.9 & 7.0 & 1994 \\
\hline 5.8 & 5.9 & 7.0 & 1995 \\
\hline 5.8 & 5.8 & 7.0 & 1996 \\
\hline 5.9 & 5.6 & 7.0 & 1997 \\
\hline 5.9 & 5.5 & 7.0 & 1998 \\
\hline 5.9 & 5.5 & 7.0 & 1999 \\
\hline 5.9 & 5.5 & 7.0 & 2000 \\
\hline 5.9 & 5.5 & 7.0 & 2001 \\
\hline 6.0 & 5.5 & 7.1 & 2002 \\
\hline 6.0 & 5.5 & 7.1 & 2003 \\
\hline 6.0 & 5.8 & 7.1 & 2004 \\
\hline 6.9 & 7.2 & 8.3 & 2005 \\
\hline 6.1 & 6 & 7.3 & 2006 \\
\hline 6.1 & 6.2 & 7.3 & 2007 \\
\hline 6.1 & 6.1 & 7.4 & 2008 \\
\hline 6.1 & 6.2 & 7.4 & 2009 \\
\hline 6.2 & 6 & 7.4 & 2010 \\
\hline 6 & 5.9 & 7.2 & $1978-2010$ \\
\hline
\end{tabular}

* nearly to the first digit.

$\mathrm{b}=02$ due to unpublished paper Sofan2008

Sources: 1977-2002 years (central bank 2004); 2003-2010 years (central bank statistical report, Vol. 41, Num. 12, 2005) 
Table 4. Comparison between, the contribution of the average total factors productivity growth rate to the average growth rate of GDP and the contribution of the average annual gross capital formation to GDP in Jordan $(1978-2010)^{*}$

\begin{tabular}{|c|c|c|c|c|}
\hline $\begin{array}{c}\text { percentage of } \\
\text { capitalto GDP\% }\end{array}$ & $\begin{array}{l}\text { Average Change to average } \\
\text { growth in total factors } \\
\text { productivity } \%\end{array}$ & $\begin{array}{l}\text { Percentage of average growth in } \\
\text { total factors productivity to GDP } \\
\text { growth rate }\end{array}$ & $\begin{array}{l}\text { GDP growth } \\
\text { rate*\% }\end{array}$ & Year \\
\hline 33.1 & 1.91 & 39.3 & 14.7 & 1978 \\
\hline 31.5 & 2.12 & 28.3 & 20,8 & 1979 \\
\hline 37.2 & 0.26 & 52.8 & 11.2 & 1980 \\
\hline 46.0 & 0.92 & 34.7 & 17.2 & 1981 \\
\hline 39.4 & 0.92 & 85.7 & 7.0 & 1982 \\
\hline 33.0 & $0.21-$ & $270.8-$ & $2.2-$ & 1983 \\
\hline 30.0 & 0.38 & 140.5 & 4.3 & 1984 \\
\hline 21.1 & 0.29 & 223.3- & $2.7-$ & 1985 \\
\hline 19.8 & 0.40 & 110.3 & 5.5 & 1986 \\
\hline 22.6 & $0.62-$ & 259.5 & 2.3 & 1987 \\
\hline 22.6 & $0.33-$ & 411.7 & 1.5 & 1988 \\
\hline 23.2 & 2.1- & 54.9- & $10.7-$ & 1989 \\
\hline 30.8 & 2.33- & 2097.5- & $0.3-$ & 1990 \\
\hline 25.0 & 0.05 & 357.7 & 1.6 & 1991 \\
\hline 33.5 & 0.03 & 10.2 & 14.4 & 1992 \\
\hline 36.6 & $0.23-$ & 128.5 & 4.5 & 1993 \\
\hline 33.3 & 0.51 & 116.0 & 5.0 & 1994 \\
\hline 33.0 & 0.45 & 94.0 & 6.2 & 1995 \\
\hline 30.5 & 0.17 & 281.3 & 2.1 & 1996 \\
\hline 25.7 & 0.66 & 176.4 & 3.3 & 1997 \\
\hline 21.8 & 0.62 & 195.7 & 3.0 & 1998 \\
\hline 21.6 & 0.11 & 193.0 & 3.1 & 1999 \\
\hline 22.2 & 0.12 & 144.3 & 4.1 & 2000 \\
\hline 20.8 & 0.53 & 121.2 & 4.9 & 2001 \\
\hline 20.1 & 0.43 & 123.9 & 4.8 & 2002 \\
\hline 20.8 & 0.08 & 145.7 & 4.1 & 2003 \\
\hline 27.1 & $0.2-$ & 77.4 & 7.7 & 2004 \\
\hline 34.1 & 15,1 & 2,9 & 235,5 & 2005 \\
\hline 28.3 & $-11,7$ & $-9,4$ & $64,2-$ & 2006 \\
\hline 30.3 & 0,5 & 74,5 & 8,2 & 2007 \\
\hline 29.9 & 0,7 & 84,8 & 7,2 & 2008 \\
\hline 26.3 & 0,8 & 113,0 & 5,5 & 2009 \\
\hline 24.8 & 0,2 & 268,3 & 2,3 & 2010 \\
\hline $28.2 \%$ & 0.32 & $37.8 \%$ & & $1978-2010$ \\
\hline
\end{tabular}

* nearly to the first digit.

Sources: 1977-2002 years (central bank 2004); 2003-2010 years (central bank statistical report, Vol. 41, Num. 12, 2005) 


\section{Results}

This study is to analyze the sources of economic growth in Jordan for the period (1978-2010), as follows:

1) Results show the source of economic growth in Jordan that the rate of economic growth depends on the intensive growth which reflects on intangible aspects that does not reflect changes visible in the accumulation of factors of production, with an average annual growth rate of total factor productivity $6 \%$ for the period 1978 2010.

2) This means that qualified labor affect economic growth through the quality of work and productivity accumulation of human capital that increase in productivity and improve the quality of production because of the skill possessed by labor, in addition to reducing the cost of its ability to use modern technological methods and ability to innovate and create, also monetary policy, the size of government expenditures, foreign trade , and inflation are considered as a factors affecting on intensive growth.

3) The average contribution to the overall growth rate of the factors of production to an average growth rate of GDP accounted for $37.8 \%$, while the average annual gross capital formation to GDP accounted for $28.2 \%$ during the study period.

4) Achieved economic and financial reforms in Jordan improvement in the productivity of all factors of production, so that the change in the proportion of the overall growth rate factor productivity was closely linked to the quality of the investment climate and the economic situation and the political events surrounding during the study period.

\section{Discussion}

Based on the objectives of this study and through our review of the findings, the study recommends:

1) The need to increase spending on improving the quality and efficiency of the workforce, including human investment spendings because the availability of qualified labor is a reason to bring a foreign investment through training for employment and education, as it maintains the long-term rate in economic growth.

2) The need to improve the quality of the investment climate, external trade policy and the political polices in the reign.

\section{References}

Barro, R. (1991). Economic Growth in a Cross Section of Countries. Quarterly Journal of Economics, 106, 407-43. http://dx.doi.org/10.2307/2937943

Creane, S., Goyal, R., Mobark, A. M., \& Sab, R. (2003). Financial Development and Economic Growth in the Middle East and North Africa. News Letter Of The Economic Research Forum for the Arab Countries, Iran, Turkey, 10(1), 4-12.

De Meulemeester, J. L., \& Rochat, D. (1995). A Causality Analysis of the Link between Higher Education and Development. Economics of Education Review. http://dx.doi.org/10.1016/0272-7757(95)00015-C

Jones, H. (1978). Modern Theories of Economic Growth. UK: Copllot Press.

Kuznets, S. (1966). Modern Economic Growth: Rate, Structure and Spread. New Haven and London: Yale University Press.

Namik, S. D. (1965). The theories of economic growth. Cairo: Knowledge House.

Narayan, P. K., \& Smyth, R. (2004). Temporal Causality and the Dynamics of Exports. Human Capital and Real Income in China.

Ramadan, Z. (1997). Banking Management. Amman: Dar Al-Safa for publication and distribution.

Romar, D. (1996). Advanced Macroeconomic (2nd ed.). Berkeley.

Shaw, E. (1973). Financial Development in Economic Growth. Oxford University, New York.

Soufan, T. (2008). The impact of financial development in economic growth in Jordan. unpublished Ph.D. thesis, University of Jordan.

Statistics. (1990-2004). Statistical Yearbook. The Research and Studies Department, Amman.

Virmani, A. (2012). Accelerating and Sustaining Growth: Economic and Political Lessons. IMF Working Papers.

Zoubi, B., \& Kassem. (2004). The impact of human capital and exports on economic growth in Jordan - A Case Study of the governorate of Irbid. A series of Human Sciences, Yarmouk University. 


\section{Copyrights}

Copyright for this article is retained by the author(s), with first publication rights granted to the journal.

This is an open-access article distributed under the terms and conditions of the Creative Commons Attribution license (http://creativecommons.org/licenses/by/3.0/). 